\title{
The Biology of Serotonin Receptors: Focus on Migraine Pathophysiology and Treatment
}

\author{
Edith Hamel
}

\begin{abstract}
Serotonin receptors are highly heterogeneous and they have been regrouped within seven different families $\left(5-\mathrm{HT}_{1}-5-\mathrm{HT}_{7}\right)$. With the exception of the 5- $\mathrm{HT}_{3}$ which is a ligand-gated ion channel, all others are G-protein coupled receptors with each family sharing structural, pharmacological and transductional characteristics. 5-HT receptors have been implicated in the regulation of several psychiatric and neurological disorders related to serotonergic neurotransmission, and specific receptor subtypes have recently been associated with either the pathogenesis or the treatment of migraine headache. In this respect, activation of vascular 5- $\mathrm{HT}_{2 \mathrm{~B}}$ and/or 5- $\mathrm{HT}_{7}$ receptors, possibly as a consequence of the sudden rise in 5-HT levels reported at the onset of a migraine attack, would hypothetically result in dilation of cerebral blood vessels and concomitant activation of sensory trigeminovascular afferents, hence initiating the manifestation of head pain. At this stage in the migraine process, activation of specific subtypes of 5-HT receptors has proven clinically effective in relieving migraine pain. Neural 5- $\mathrm{HT}_{1 \mathrm{D}}$ and/or 5- $\mathrm{HT}_{1 \mathrm{~F}}$ receptors localized pre-junctionally on trigeminovascular afferents appear to mediate the triptan-induced inhibition of the neurogenic inflammatory response, with possible additional sites of action for brain penetrant 5-HT 1 receptor agonists in inhibiting the transmission of pain centrally. In contrast, activation of vascular 5- $\mathrm{HT}_{1 \mathrm{~B}}$ receptors would constrict meningeal vessels hence recovering their pre-migraine diameter. The recent availability of subtype selective $5-\mathrm{HT}_{1 \mathrm{D}}$ and $5-\mathrm{HT}_{1 \mathrm{~F}}$ receptor agonists should allow a further test of the neural/vascular hypothesis and could possibly lead to antimigraine drugs with a safer cardiovascular profile.
\end{abstract}

RÉSUMÉ:Biologie des récepteurs sérotoninergiques.Les récepteurs sérotoninergiques sont très hétérogènes. On les a regroupés en 7 familles différentes $\left(5-\mathrm{HT}_{1}-5-\mathrm{HT}_{7}\right)$. À l'exception de $5 \mathrm{HT}_{3}$ qui appartient à la famille des récepteurs canaux, tous les autres appartiennent à la famille des récepteurs couplés à la protéine $\mathrm{G}$ et chaque famille a des caractéristiques structurales, pharmacologiques et transductionnelles communes. Les récepteurs 5-HT ont été impliqués dans la régulation de plusieurs maladies psychiatriques et neurologiques reliées à la neurotransmission sérotoninergique et des sous-types de récepteurs spécifiques ont été associés récemment à la pathogenèse ou au traitement de la migraine. À ce sujet, l'activation de récepteurs vasculaires 5- $\mathrm{HT}_{2 \mathrm{~b}}$ et/ou 5- $\mathrm{HT}_{7}$, possiblement comme conséquence de la hausse soudaine des niveaux de 5-HT rapportés au début d'un accès de migraine, provoquerait hypothétiquement une dilatation des vaisseaux sanguins cérébraux et une activation concomitante des afférents trigéminovasculaires sensitifs, amorçant ainsi la manifestation de la céphalée. À ce stage dans le processus migraineux, l'efficacité de l'activation de sous-types spécifiques de récepteurs 5 -HT $\mathrm{HT}_{1}$ pour soulager la douleur migraineuse a été démontrée en clinique. Les récepteurs neuronaux 5- $\mathrm{HT}_{1 \mathrm{D}}$ et/ou 5-HT $\mathrm{HF}_{1 \mathrm{~F}}$ localisés en présynapse sur les afférents trigéminovasculaires semblent médier l'inhibition de la réponse inflammatoire neurogène induite par le triptan. Il est également possible qu'il existe des sites additionnels pour les agonistes des récepteurs 5-HT qui pénètrent dans le cerveau et qui inhibent la transmission centrale de la douleur. Par ailleurs, l'activation des récepteurs vasculaires $5-\mathrm{HT}_{1 \mathrm{~B}}$ provoquerait une vasoconstriction des vaisseaux méningés qui reprendraient ainsi leur diamètre pré-migraine. L'arrivée d'agonistes sélectifs pour les sous-types de récepteurs $5-\mathrm{HT}_{1 \mathrm{D}}$ et 5 - $\mathrm{HT}_{1 \mathrm{~F}}$ devrait permettre de tester l'hypothèse nerveuse/vasculaire et pourrait peut-être mener au développement de médicaments antimigraineux ayant un profil cardiovasculaire plus sûr.

Can. J. Neurol. Sci. 1999; 26: Suppl. 3-S2-S6

Serotonin (5-hydroxytryptamine, 5-HT) is a widespread neuromodulator which performs a variety of functions in the central and peripheral nervous systems, as well as in tissues such as the blood vessels. Serotonin is involved in several psychiatric and neurological disorders ${ }^{1,2,3}$ and, more specifically, in the pathogenesis of migraine headache. ${ }^{4}$ These

From the Montreal Neurological Institute, McGill University, Montreal, QC, Canada Reprint requests to: Edith Hamel, Montreal Neurological Institute, 3801 University Street, Montreal, QC, H3A2B4 
conditions may result from inadequate neurotransmission, and hence in dysfunctional interactions between 5-HT and its preand/or post-synaptic receptors. 5-HT receptors are highly heterogeneous and the advent of molecular biology has allowed the cloning of several pharmacologically characterized receptors but also of new, so far unsuspected 5-HT receptors. Together with the availability of new pharmacological tools, these developments have provided new insights into the role of specific types of 5-HT receptors in the neurobiology of migraine headache. The present paper will briefly consider the different families of 5-HT receptors and will then focus more specifically on those that have attracted attention either in the aetiology or in the treatment of migraine headache. For a more detailed description of different aspects of 5-HT receptors, in terms of molecular, functional and pharmacological properties, extensive reviews are available. , $3,5^{2}$

\section{HETEROGENEITY OF 5-HT RECEPTORS}

Based on the recommended International Union of Pharmacology (IUPHAR), 5-HT receptors have been classified into seven different families (5-HT 1 to $\left.5-\mathrm{HT}_{7}\right) .{ }^{1,5}$ Except for the $5-\mathrm{HT}_{3}$ receptor which is a ligand-gated ion channel, all other receptors belong to the superfamily of G-protein-coupled receptors with seven transmembrane domains. Receptors within a single family share high homology in their amino acid sequence identity, they couple to the same second messenger systems and, although they display an overall typical pharmacological profile, individual receptors can be discriminated if subtype-selective pharmacological tools are available. Based on the IUHPAR nomenclature, receptors are written in upper case letter when they fulfill all molecular, pharmacological and functional criteria in biological tissues but those still lacking a biological role are listed in lower case letters.

5-HT 1 receptors represent the largest subfamily of 5-HT receptors and they typically exhibit a high affinity for 5-HT. They are subdivided into 5- $\mathrm{HT}_{1 \mathrm{~A}}, 5-\mathrm{HT}_{1 \mathrm{~B}}, 5-\mathrm{HT}_{1 \mathrm{D}}, 5-\mathrm{ht}_{1 \mathrm{E}}$ and 5$\mathrm{HT}_{1 \mathrm{~F}}$ receptors, all of which are coupled to inhibition of adenylate cyclase activity. ${ }^{3,4}$ More specifically, 5-HT $1 \mathrm{~A}$ receptors have been implicated in the regulation of many functions, including feeding behaviour, body temperature, and in disorders such as depression and anxiety. ${ }^{1,2}$ At present, there is no strong evidence to suggest that this receptor subtype would be selectively involved in migraine headache. However, it should be kept in mind that $5-\mathrm{HT}_{1}$ receptor agonists such as sumatriptan, the new triptan derivatives and other compounds such as the ergotamine and dihydroergotamine exhibit a relatively high affinity at $5-\mathrm{HT}_{1 \mathrm{~A}}$ receptors via which they may regulate nausea and vomiting responses. ${ }^{4}$

When first identified, 5- $\mathrm{HT}_{1 \mathrm{~B}}$ and 5- $\mathrm{HT}_{1 \mathrm{D}}$ receptor subtypes were strictly impossible to discriminate on a pharmacological basis, except for a few compounds such as ketanserin and ritanserin which exert antagonistic activity at 5- $\mathrm{HT}_{1 \mathrm{D}}$ but not 5$\mathrm{HT}_{1 \mathrm{~B}}$ receptors. ${ }^{6}$ The cloning of two distinct genes for the 5$\mathrm{HT}_{1 \mathrm{~B}}$ and 5-HT $\mathrm{HD}_{1 \mathrm{D}}$ receptors then allowed for a better insight into their distribution and expression in different tissues., ${ }^{1,3}$ However, localization of their mRNA expression within brain tissues has shown several areas of overlap and it is still quite difficult to ascertain their respective roles. Together, these $5-\mathrm{HT}_{1}$ receptors have been implicated in depression, anxiety, movement disorders, and food intake. ${ }^{1,2}$ More recently, the role of $5-\mathrm{HT}_{1 \mathrm{~B} / 1 \mathrm{D}}$ receptors in aborting migraine headache has been quite well elucidated (see below).

The cloning of 5-ht ${ }_{1 \mathrm{E}}$ and $5-\mathrm{HT}_{1 \mathrm{~F}}$ receptors has revealed their high sequence homology, and expression of mRNA for these two receptors has been found in the peripheral and/or central nervous system. Their coupling to adenylate cyclase activity appears to be less well defined than that of the other 5-HT receptors and they may also couple to other signalling pathways. ${ }^{3,5}$ Although no definite function has been ascribed for these two receptor subtypes, recent evidence suggest that the 5$\mathrm{HT}_{1 \mathrm{~F}}$ receptor may be able to modulate the release of neurotransmitter from the trigeminovascular system, and as such, it has been implicated in the pathophysiology/treatment of migraine headache. ${ }^{7}$

$5-\mathrm{HT}_{2}$ receptors have been involved in a plethora of functions spanning from smooth muscle contraction, transmitter release, sexual activity, appetite, sleep, locomotion, regulation of cerebrospinal fluid exchange, neurological and psychiatric disorders, and also migraine. ${ }^{2}$ Three subtypes constitute this receptor subfamily, namely $5-\mathrm{HT}_{2 \mathrm{~A}}$ (the classical $5-\mathrm{HT}_{2}$ receptor), 5- $\mathrm{HT}_{2 \mathrm{~B}}$ (highly expressed in stomach fundus and originally referred to as $5-\mathrm{HT}_{2 \mathrm{~F}}$ ), and the $5-\mathrm{HT}_{2 \mathrm{C}}$ (former $5-$ $\left.\mathrm{HT}_{1 \mathrm{C}}\right)$ receptors. These receptors characteristically exhibit a lower affinity for 5-HT than 5-HT 1 receptors, and they positively couple to phospholipase C. $5-\mathrm{HT}_{2 \mathrm{~A}}$ receptors exist at high levels in many brain areas, while $5-\mathrm{HT}_{2 \mathrm{~B}}$ receptors are reportedly expressed at low levels in human brain and $5-\mathrm{HT}_{2 \mathrm{C}}$ receptors are primarily enriched in the choroid plexus although they also overlap in their distribution with $5-\mathrm{HT}_{2 \mathrm{~A}}$ receptors. ${ }^{2,3,5}$ As will be described below, the originally suspected role for 5$\mathrm{HT}_{2 \mathrm{~A}}$ and $5-\mathrm{HT}_{2 \mathrm{C}}$ receptors in migraine pathogenesis has recently been superseded by a most probable implication of 5$\mathrm{HT}_{2 \mathrm{~B}}$ receptors in the disease process.

The 5-HT $\mathrm{H}_{3}$ receptor represents the only ligand-gated ion channel 5-HT receptor, its activation leads to rapid increase in $\mathrm{Na}^{+} / \mathrm{K}^{+}$conductance and a subsequent influx of extracellular $\mathrm{Ca}^{2+}$ and, in brain, it appears to be primarily composed of the heteromeric assembly of $5-\mathrm{HT}_{3 \mathrm{~A}}$ and $5-\mathrm{HT}_{3 \mathrm{~B}}$ subunits. ${ }^{8} 5-\mathrm{HT}_{3}$ receptors are located in the peripheral and central nervous system where high levels are found in the nucleus tractus solitarius and the area prostrema, area of the brain emetic center. This localization most probably accounts for the original interest for $5-\mathrm{HT}_{3}$ receptor antagonists in the treatment of migraine headache. $5-\mathrm{HT}_{3}$ receptor antagonists indeed behave as antiemetic agents and are commonly used in cancer patients undergoing chemotherapy, however, they have not sustained a great interest in the treatment of migraine-associated symptoms over the recent years. A role for $5-\mathrm{HT}_{3}$ receptors in the modulaton of cranial nociception has also been suggested. ${ }^{4,9}$ The cloning of a new $5-\mathrm{HT}_{3}$ receptor subunit ${ }^{8}$ further suggests that additional work is needed to clarify if $5-\mathrm{HT}_{3}$ receptors may still represent an interesting target in the management of migraine headache.

5-HT 4 5-ht ${ }_{5}$ and 5-ht ${ }_{6}$ receptors have been cloned in human tissues and found in peripheral organs and/or in brain, however, very little is known about the roles of these 5-HT receptors (for more details, see ${ }^{3,5}$ ). 5- $\mathrm{HT}_{4}$ and 5-ht 6 receptors seem to both 
increase adenylate cyclase activity whereas a definite coupling system has not yet been identified for the $5-\mathrm{ht}_{5}$ receptors. Two isoforms of 5- $\mathrm{HT}_{4}$ receptors have been reported, ${ }^{10}$ two different subtypes of $5-\mathrm{HT}_{5}$ receptors $\left(5-\mathrm{ht}_{5 \mathrm{~A}}\right.$ and $\left.5-\mathrm{ht}_{5 \mathrm{~B}}\right)$ have been cloned, ${ }^{4}$ thus suggesting that much remains to be done in order to better understand the biology of these specific types of 5-HT receptors. 5- $\mathrm{HT}_{6}$ receptors exhibit good affinity for many antipsychotic and antidepressants and they may be involved in such functions. ${ }^{3}$ No data exist at this point to suggest that either of these receptors could play a role in migraine biology.

5- $\mathrm{HT}_{7}$ receptors, like the $5-\mathrm{HT}_{4}$ and $5-\mathrm{ht}_{6}$ receptors are positively coupled to adenylate cyclase activity, exhibit high affinity for a variety of antipsychotic drugs, and they may exist in multiple isoforms, ${ }^{11}$ a finding which will deserve further investigation of their putative respective roles. $5-\mathrm{HT}_{7}$ receptors are discretely distributed in brain, mainly in the hippocampus, thalamic and limbic structures as well as in many other areas such as the spinal trigeminal nucleus. ${ }^{3,5,11}$ They are also present in many peripheral and cerebral blood vessels where they mediate an endothelium-independent dilation. ${ }^{11,12}$ Roles in affective behaviour, circadian rhythm and, possibly, migraine headache ${ }^{13}$ have been recently suggested.

\section{5-HT RECEPTORS: RELEVANCE TO MIGRAINE PATHOGENESIS AND TREATMENT}

\section{5-HT 1 receptors in migraine headache}

It is undeniable that the cloning of $5-\mathrm{HT}_{1 \mathrm{~B}}$ and $5-\mathrm{HT}_{1 \mathrm{D}}$ receptors and the development of the $5-\mathrm{HT}_{1 \mathrm{~B} / 1 \mathrm{D} / 1 \mathrm{~F}}$ receptor full agonist sumatriptan have revolutionized not only our ability to offer adequate treatment to more migraine sufferers but also our understanding of the neurobiology of migraine headache. Sumatriptan, originally developed to induce contraction of the putatively distended blood vessels during a migraine attack, and then found to potently inhibit the neurogenic inflammatory response resulting from activation of the trigeminovascular system, ${ }^{14}$ has led the impetus towards the identification of these respective vascular and neuronal 5- $\mathrm{HT}_{1}$ sites of action. Moreover, recently developed brain penetrant triptan derivatives may offer an additional central locus of action through interaction with $5-\mathrm{HT}_{1}$ receptors able to interrupt the transmission of vascular pain centrally. ${ }^{5,15,16}$ The relative importance of the different $5-\mathrm{HT}_{1}$ receptor subtypes in the treatment of migraine headache may be appreciated when considering the meningeal neurogenic inflammation model proposed by Lance, Moskowitz and Fozard ${ }^{17}$ and characterized at length by Moskowitz and colleagues. Although this model has not been proven in man, reports of increased levels of calcitonin-gene related peptide (CGRP) in the jugular venous outflow during a migraine attack and their normalization after treatment with sumatriptan concomitantly with the relief of migraine symptoms, ${ }^{18}$ has provided arguments for activation of the trigeminovascular system in migraine sufferers.

\section{Vascular 5-HT ${ }_{1 \mathrm{~B}}$ receptors}

Current pharmacological, molecular and morphological evidence indicate that the $5-\mathrm{HT}_{1}$ receptor which mediates the sumatriptan-induced contraction of the meningeal blood vessels corresponds primarily, if not exclusively, to a $5-\mathrm{HT}_{1 \mathrm{~B}}$ receptor localized on the smooth muscle cells of brain vessels..$^{19,20,21}$ However, in contrast to the original claim that sumatriptan could act on receptors that are unique to cerebral blood vessels, it has now been clearly demonstrated that vasocontractile $5-\mathrm{HT}_{1 \mathrm{~B}}$ receptors are also present in peripheral blood vessels such as the human coronary artery. ${ }^{22}$ Such findings indicate that all $5-\mathrm{HT}_{1}$ receptor agonists with affinity at the $5-\mathrm{HT}_{1 \mathrm{~B}}$ subtype share a similar potential risk of undesirable cardiovascular effects, a property which might be a contraindication in some patients.

\section{Neuronal 5-HT 1 and 5-HT 1F $_{1 \mathrm{D}}$ sites of action}

As mentioned above, activation of trigeminovascular afferents has been suggested as an important initiator of head pain. Once activated, these nerve fibers have the ability to release neuropeptides such as CGRP, substance $P$ and neurokinin $\mathrm{A}^{14}$ and to promote the neurogenic inflammatory response thought to be important in the sensitization of the sensory afferents, as well as in the generation and transmission of head pain centrally. ${ }^{4}$ The ability of sumatriptan and other related compounds to act on pre-junctional 5- $\mathrm{HT}_{1}$ receptors that inhibit neurogenic inflammation (characterized in animal models by protein extravasation and dilation of meningeal blood vessels) has been attributed to interaction with a 5-HT and, possibly, a $5-\mathrm{HT}_{1 \mathrm{~F}}$ receptor. $^{6,21}$ In support of these conclusions are the findings that $\mathrm{mRNA}$ and/or proteins for 5$\mathrm{HT}_{1 \mathrm{D}}{ }^{20,21}$ and $5-\mathrm{HT}_{1 \mathrm{~F}}{ }^{20}$ receptors are expressed in human trigeminal ganglia. Interestingly, although $5-\mathrm{HT}_{1 \mathrm{~B}}$ receptor mRNA and protein are present in human trigeminal ganglion neurons, ${ }^{20}$ immunocytochemical evidence suggests that this receptor is not transported to terminals either peripherally on trigeminovascular afferents or centrally in the nucleus trigeminalis caudalis. Interestingly, the recent report that sumatriptan can directly repress CGRP gene transcription from sensory trigeminal neurons ${ }^{23}$ may offer additional cellular targets to explain its antimigraine efficacy. More studies will be needed to clearly identify this trigeminal $5-\mathrm{HT}_{1}$ receptor as well as those localized in the brainstem in order to assess the respective role, if any, of the various $5-\mathrm{HT}_{1}$ receptors in neurogenic inflammation and central pain transmission. It should also be noted that $5-\mathrm{HT}_{1 \mathrm{~B} / 1 \mathrm{D}}$ and $5-\mathrm{HT}_{1 \mathrm{~F}}$ receptors are present in multiple locations within the human brain ${ }^{24}$ and their possible activation by brain penetrant $5-\mathrm{HT}_{1}$ receptor agonists deserves further investigation.

\section{5-HT ${ }_{2 \mathrm{~B}}$ and/or $5-\mathrm{HT}_{7}$ receptors in migraine pathogenesis}

A landmark characteristic of commonly used compounds in migraine prophylaxis (e.g. pizotifen, methysergide, cyproheptadine, amitriptyline) is reportedly their antagonistic property at 5$\mathrm{HT}_{2 \mathrm{~B}}$, but not 5- $\mathrm{HT}_{2 \mathrm{~A}}$ and $5-\mathrm{HT}_{2 \mathrm{C}}$, receptors. ${ }^{25}$ In this respect, the similarity between the pharmacological profile of these antimigraine prophylactic agents and that of an endothelial 5-HT receptor mediating a nitric oxide (NO)-dependent dilation led to the hypothesis that activation of endothelial $5-\mathrm{HT}_{2 \mathrm{~B}}$ receptors would result not only in dilation of the cerebral blood vessels but also in the activation of the trigeminovascular afferents. ${ }^{26}$ Clearly this aspect of migraine pathogenesis is reductionist as it again targets the pathway of vascular head pain and ignores all neuronal events that may also be altered in patients receiving prophylactically $5-\mathrm{HT}_{2}$ receptor antagonists. Whether specific 
populations of $5-\mathrm{HT}_{2}$ receptors have been differentially regulated by such chronic treatments still remains unknown.

Despite this possible drawback, support for a role of vascular $5-\mathrm{HT}_{2 \mathrm{~B}}$ receptors in triggering migraine headache includes the selective expression of $5-\mathrm{HT}_{2 \mathrm{~B}}$ receptor message in human brain vessels, ${ }^{27,28}$ and endothelial cells, ${ }^{28}$ and their reported ability, albeit in the pig, to induce an NO-dependent cerebral dilation. ${ }^{27}$ Although more studies will be required to confirm such a role in human brain vessels, it is interesting that activation of these receptors in porcine cerebral vessels seems to promote the synthesis and release of $\mathrm{NO},{ }^{27}$ a molecule known as an effective activator of trigeminovascular afferents. ${ }^{29}$ In this respect, the recently reported efficacy of NO synthase inhibitors in the treatment of migraine headache ${ }^{30}$ brings support for NO contributing to the pathogenesis of migraine headache. However, the constitutive nature of the NOS involved as well as the endothelial and/or neuronal origin of NO remain to be identified in order for this hypothesis to be proven true in the human situation.

Recently, a similar argument has been made with the 5$\mathrm{HT}_{7}$ receptors. Indeed, as for the 5- $\mathrm{HT}_{2 \mathrm{~B}}$ receptors, a highly significant correlation has been found between the effective clinical doses of several prophylactic antimigraine compounds and their antagonistic affinity at $5-\mathrm{HT}_{7}$ receptors. ${ }^{12,13}$ These receptors can induce cerebral dilation through a direct action on the smooth muscle, ${ }^{11,12}$ they are expressed and functional in human brain vessels and vascular smooth muscle cells ${ }^{31}$ and they could thus play a role in regulating cerebrovascular tone. It is possible that during a migraine headache, the rise in serotonergic tone could result in a $5-\mathrm{HT}_{7}$-mediated increase in vessel diameter that could excite sensory trigeminovascular nerve terminals, which upon activation would initiate the neurogenic trigeminovascular inflammatory response. Additional experiments are needed to clarify this possibility as well as that of a direct role for pre-junctional 5- $\mathrm{HT}_{7}$ receptors on trigeminovascular afferents.

\section{Conclusion}

Specific populations of 5-HT receptors seem to be involved in the pathogenesis and treatment of migraine headache. Most interesting is the fact that while 5- $\mathrm{HT}_{2 \mathrm{~B}}$ and/or 5- $\mathrm{HT}_{7}$ receptors are putatively implicated in the initiation of migraine pain, 5$\mathrm{HT}_{1 \mathrm{~B} / 1 \mathrm{D}}$ and/or 5-HT $\mathrm{HF}_{1 \mathrm{~F}}$ receptors appear as potent inhibitors of this symptom. These findings again underscore the complexity of serotonergic mechanisms and how different receptor populations can exert distinct functional responses. It is clear that changes in serotonergic status alone cannot explain the full array of the symptoms associated with migraine, but it is also impressive to realize how much the discovery of the different 5$\mathrm{HT}_{1}$ receptor subtypes has improved the treatment of migraine headache. It is hoped that the advent of subtype-selective 5$\mathrm{HT}_{1 \mathrm{D}}$ and $5-\mathrm{HT}_{1 \mathrm{~F}}$ receptor agonists will similarly expand our understanding of the basic mechanisms that underlie these symptoms, and possibly lead to antimigraine drugs with better cardiovascular safety. Further studies will be needed to prove the clinical efficacy of such $5-\mathrm{HT}_{1}$ selective compounds, as well as the involvement of neuronal and/or vascular 5-HT receptors in the initiation of the vascular head pain.

\section{ACKNOWLEDGEMENTS}

The author thanks the Medical Research Council of Canada and the Heart and Stroke Foundation of Québec for supporting the work performed in her laboratory, as well as Ms L. Michel for preparing the manuscript.

\section{REFERENCES}

1. Martin GR, Humphrey PPA. Receptors for 5-hydroxytryptamine: current perspectives on classification and nomenclature. Neuropharmacology 1994; 33: 261-273.

2. Pandey SC, Davis JM, Pandey GN. Phosphoinositide systemlinked serotonin receptor subtypes and their pharmacological properties and clinical correlates. J Psychiatry Neurosci 1995; 20: $215-225$.

3. Gerhardt CC, van Heerikhuizen H. Functional characteristics of heterologously expressed 5-HT receptors. Eur J Pharmacol 1997; 334: 1-23.

4. Martin GR. Serotonin receptor involvement in the pathogenesis and treatment of migraine. In: Silberstein S, Goadsby PJ, eds. Headache Blue Books of Practical Neurology, Volume 17, Chapter 2. Butterworth-Heineman, 1997; 25-38.

5. Hoyer D, Martin G. 5-HTreceptor classification and nomenclature: towards a harmonization with the human genome. Neuropharmacology 1997; 36: 419-428.

6. Zgombick JM, Schechter LE, Kucharewicz SA, Weinshank RLand Bracnchek TA. Ketanserin and ritanserin discriminate between recombinant human $5-\mathrm{HT}_{1 \mathrm{D} \alpha}$ and $5-\mathrm{HT}_{1 \mathrm{D} \beta}$ receptor subtypes. Eur J Pharmacol 1995; 291:9-15.

7. Phebus LA, Johnson KW, Zgombick JM, et al. Characterization of LY344864 as a pharmacological tool to study $5-\mathrm{HT}_{1 \mathrm{~F}}$ receptors: binding affinities, brain penetration and activity in the neurogenic dural inflammation model of migraine. Life Sci 1997; 61: 2117-2126.

8. Davies PA, Pistis M, Hanna MC, Peters JA, Lambert JJ, Hales, TG and Kirkness, EF. The 5-HT3B subunit is a major determinant of serotonin-receptor function. Nature 1999; 397:359-363.

9. Dahlöf CGH, Hargreaves RJ. Pathophysiology and pharmacology of migraine. Is there a place for antiemetics in future treatment strategies? Cephalalgia 1998; 18: 593-604.

10. Bockaert J, Fozard JR, Dumuis A, Clarke DE. The 5-HT ${ }_{4}$ receptor: a place in the sun. Trends Pharmacol Sci 1992; 13: 141-145.

11. Eglen RM, Jasper JR, Chang DJ, Martin GR. The 5-HT 7 receptor: orphan found. Trends Pharmacol Sci 1997; 18:104-107.

12. Terron JA. The 5- $\mathrm{HT}_{7}$ receptor: a target for novel therapeutic avenues? Drugs 1998; 1: 302-310.

13. Terron JA. Involvement of the $5-\mathrm{HT}_{7}$ receptor in cerebrovascular vasodilation: potential impact in migraine. Proc West Pharmacol Soc 1998; 41: 247-251.

14. Moskowitz MA. Neurogenic versus vascular mechanisms of sumatriptan and ergot alkaloids in migraine. Trends Pharmacol Sci 1992; 13: 307-311.

15. Storer RJ, Goadsby PJ. Microiontophoretic application of serotonin $(5 \mathrm{HT})_{1 \mathrm{~B} / \mathrm{DD}}$ agonists inhibits trigeminal cell firing in the cat. Brain 1997; 120: 2171-2177.

16. Goadsby PJ. Is a central action of acute antimigraine drugs essential? Cephalalgia 1997; 17(Suppl): 10-11.

17. Fozard JR. The pharmacological basis of migraine treatment. In: Blau JN, ed. Migraine: Clinical and Research Aspects, Chapter 10. Baltimore: The Johns Hopkins University Press, 1987; 165-184.

18. Goadsby PJ, Edvinsson L. The trigeminovascular system and migraine: studies characterizing cerebrovascular and neuropeptide changes seen in humans and cats. Ann Neurol 1993; 33: 48-56.

19. Hamel E, Fan E, Linville D, et al. Expression of mRNA for the serotonin 5-hydroxytryptamine ${ }_{1 \mathrm{D} \beta}$ receptor subtype in human and bovine cerebral arteries. Mol Pharmacol 1993; 44: 242-246.

20. Bouchelet I, Cohen Z, Case B, Séguéla P, Hamel E. Differential expression of sumatriptan-sensitive 5-hydroxytryptamine receptors in human trigeminal ganglia and cerebral blood vessels. Mol Pharmacol 1996; 50: 219-223. 
21. Longmore J, Shaw D, Smith D, et al. Differential distribution of $5 \mathrm{HT}_{1 \mathrm{D}^{-}}$and $5 \mathrm{HT}_{1 \mathrm{~B}}$-immunoreactivity within the human trigemino-cerebrovascular system: implications for the discovery of new antimigraine drugs. Cephalalgia 1997; 17: 833-842.

22. MaassenVanDenBrink A, Reekers M, Bax WA, Ferrari MD, Saxena PR. Coronary side-effect potential of current and prospective antimigraine drugs. Circulation 1998; 98: 25-30.

23. Durham PL, Sharma RV and Russo AF. Repression of the calcitonin gene-related peptide promoter by $5-\mathrm{HT}_{1}$ receptor activation. J Neurosci 1997; 17:9545-9553.

24. Pascual J, del Arco D, Romon T, et al. Autoradiographic distribution of $\left[{ }^{3} \mathrm{H}\right]$ sumatriptan-binding sites in post-mortem human brain. Cephalalgia 1996; 16: 317-322.

25. Fozard JR, Kalkman HO. 5-Hydroxytryptamine (5-HT) and the initiation of migraine: new perspectives. Naunyn-Schmiedeberg's Arch Pharmacol 1994; 350: 225-229.

26. Kalkman $\mathrm{HO}$. Is migraine prophylactic activity caused by $5-\mathrm{HT}_{2 \mathrm{~B}}$ or 5-HT2C receptor blockade? Life Sci 1994; 54: 641-644.
27. Schmuck K, Ullmer C, Kalkman HO, Probst A, Lubbert $\mathrm{H}$. Activation of meningeal 5- $\mathrm{HT}_{2 \mathrm{~B}}$ receptors: an early step in the generation of migraine headache? Eur J Neurosci 1996;8:959-967.

28. Bouchelet I, Cohen Z, Stanimirovic D, Hamel E. Endothelial 5$\mathrm{HT}_{2 \mathrm{~B}}$, but not 5-HT $\mathrm{HT}_{2 \mathrm{C}}$, receptors in human brain vessels: possible role in migraine headache. J Cereb Blood Flow Metab 1997; 17(Suppl 1): S351.

29. Wei EP, Moskowitz MA, Boccalini P, Contos HA. Calcitonin generelated peptide mediates nitroglycerin and sodium nitroprussideinduced vasodilation in feline cerebral arteries. Circ Res 1992; 70: 1313-1319.

30. Lassen LH, Ashina M, Christiansen I, et al. Nitric oxide synthase inhibition: a new principle in the treatment of migraine attacks. Cephalalgia 1998; 18: 27-32.

31. Cohen Z, Bouchelet I, Olivier A, et al. Multiple microvascular and astroglial 5-hydroxytryptamine receptor subtypes in human brain: molecular and pharmacological characterization. J Cereb Blood Flow Metab 1999; 19: 908-917. 